\title{
Protective effects of L-glutamine against toxicity of deltamethrin in the cerebral tissue
}

\author{
This article was published in the following Dove Press journal: \\ Neuropsychiatric Disease and Treatment \\ 21 April 2016 \\ Number of times this article has been viewed
}

\author{
Sefer Varol \\ Hasan Hüseyin Özdemir \\ Mehmet Uğur Çevik \\ Yașar Altun \\ Ibrahim Ibiloğlu \\ Aysun Ekinci \\ Aslıhan Okan Ibiloğlu \\ Metin Balduz \\ Demet Arslan \\ Recep Tekin \\ Fesih Aktar \\ Mehmet Ufuk Aluçlu \\ Department of Neurology, \\ Faculty of Medicine, Dicle University, \\ Diyarbakır, Turkey
}

\begin{abstract}
Background: Deltamethrin (DLM) is a broad-spectrum synthetic dibromo-pyrethroid pesticide that is widely used for agricultural and veterinary purposes. However, human exposure to the pesticide leads to neurotoxicity. Glutamine is one of the principal, free intracellular amino acids and may also be an antioxidant. This study was undertaken in order to examine the neuroprotective and antioxidant potential of L-glutamine against DLM toxicity in female Wistar albino rats.
\end{abstract}

Materials and methods: The rats were divided into the following groups $(n=10)$ : Group I: control (distilled water; $10 \mathrm{~mL} / \mathrm{kg}$, po one dose), Group II: L-glutamine (1.5 g/kg, po one dose), Group III: DLM (35 mg/kg, po one dose), and Group IV: DLM (35 mg/kg, po one dose) and L-glutamine ( $1.5 \mathrm{~g} / \mathrm{kg}$, po one dose after 4 hours). Total oxidant status (TOS), total antioxidant status (TAS), tumor necrosis factor- $\alpha$, interleukin (IL)-1 $\beta$, and IL-6 levels and apoptosis were evaluated in brain tissue.

Results: DLM-treated animals had a significant increase in brain biochemical parameters, as well as TOS and TAS. Furthermore, the histopathological examination showed neuronal cell degeneration in the cerebral tissue. L-Glutamine treatment decreased the elevated brain levels of TOS and neuronal cell degeneration. There was no difference in tumor necrosis factor- $\alpha$, IL-1 $\beta$, and IL-6 levels between the groups.

Conclusion: L-Glutamine may reduce the toxic effects of DLM in the cerebral tissue through antioxidant properties.

Keywords: deltamethrin, L-glutamine, rat

\section{Introduction}

Pyrethroids are neurotoxic insecticides used in a variety of indoor and outdoor applications. Pyrethroids are classified into two types: type I pyrethroids affecting sodium channels in nerve membranes and producing repetitive neuronal discharge and prolonged negative after-potential and type II pyrethroids producing even longer delay in sodium channel inactivation leading to a persistent depolarization of the nerve membrane without repetitive discharge. ${ }^{1}$ Structurally, a key difference between type I and type II pyrethroids is the absence and presence, respectively, of $\alpha$-cyano group at the $\alpha$ carbon of the 3-phenoxybenzyl alcohol moiety of the compound. Deltamethrin (DLM), a synthetic type II pyrethroid, is a broad-spectrum synthetic dibromo-pyrethroid insecticide [ $\alpha$-cyano-3-phenoxybenzyl-(1R,S)-cis,trans-3-(2,2dibromovinyl)-2,2-dimethylcyclopropanecarboxylate] widely used to protect agricultural crops, vegetables, and fruits against pests, such as ants, mites, beetles, and weevil. It represents an environmental and industrial pollutant that is toxic to animals, birds, fish, and human beings living in the same ecosystem, as well as those directly or indirectly at risk of exposure, leading to substantial hazards. ${ }^{2}$ It is used in various
Correspondence: Mehmet Uğur Çevik Dicle University, Faculty of Medicine, Department of Neurology, Sur,

Diyarbakır, Turkey, 21280

Tel +904122488016

$\mathrm{Fax}+904122488523$

Email mehmetugur.cevik@gmail.com
Neuropsychiatric Disease and Treatment 2016:12 1005-10II

Dovepress

http://dx.doi.org/10.2147/NDT.S10401 I (c) (1) (-) 2016 Varol et al. This work is published and licensed by Dove Medical Press limited. The full terms of this license are available at https://www.dovepress.com/terms.php C. hereby accept the Terms. Non-commercial uses of the work are permitted without any further permission from Dove Medical Press Limited, provided the work is properly attributed. For permission for commercial use of this work, please see paragraphs 4.2 and 5 of our Terms (https://www.dovepress.com/terms.php). 
agricultural, home, and landscaping settings; thus, it poses a risk for accidental exposure. According to the World Health Organization, $\sim 3$ million cases of pesticide poisonings occur annually and an excess of 250,000 deaths worldwide have been reported. ${ }^{3}$ Direct exposure to DLM vapors and the consumption of polluted food and water are the most common routes of intoxication. ${ }^{4}$

The main mechanism of DLM is acaricidal, and its insecticidal effects are believed to result from its binding to a distinct receptor site on voltage-gated sodium channels, which prolong the open state by inhibiting channel deactivation and inactivation. ${ }^{5,6}$ A number of studies on the side effects of this insecticide have been reported, including hepatotoxicity, nephrotoxicity, allergy, immunosuppression, and cardiovascular and reproductive side effects. ${ }^{7}$ Acute exposure to DLM can elicit neurotoxicity and can be characterized by ataxia, loss of coordination, hyperexcitation, tremors, convulsions, and paralysis. ${ }^{8}$

L-Glutamine is the most abundant amino acid in the body, the regulator of protein synthesis and degradation. Furthermore, it plays an important role in regulating the acid-base balance, promoting immune function, and improving adaptation to stress. ${ }^{9,10}$ L-Glutamine is the precursor of glutathione (GSH), which is the most important antioxidant in the body and has been shown to improve outcome after experimental and clinical models of critical illness. ${ }^{11}$ As the precursor of GSH synthesis, glutamine contributes to antioxidant defense, as well. ${ }^{12}$

The oral administration of L-glutamine in DLM-induced hepatotoxicity is understood, but the protective effects of L-glutamine against DLM toxicity in cerebral tissue remain unknown. ${ }^{13}$ The aim of this study was to explore the effects of glutamine posttreatment on neurotoxic DLM in cerebral tissue, as well as to investigate the underlying mechanisms. In the DLM toxicity process, proinflammatory and oxidative stress mediators are released, including tumor necrosis factor- $\alpha$ (TNF- $\alpha)$, interleukin-1 $\beta$ (IL-1 $\beta$ ), interleukin 6 (IL-6), total antioxidant status (TAS), and total oxidant status (TOS). Thus, the aim of this study was to verify the levels of TNF- $\alpha$, IL-1 $\beta$, IL-6, TAS, and TOS in the rat brain following DLM toxicity and after L-glutamine treatment. Furthermore, histological assessments were carried out.

\section{Materials and methods}

\section{Animals and drug treatment}

All experiments were performed on 8-week-old female Wistar albino rats (weighing 250-260 g; Dicle University, Diyarbakır, Turkey). The rats were given a standard laboratory diet and water and were cared for under a protocol approved by the Institutional Animal Care and Use Committee of Dicle University Medical School. This study was approved by Dicle the University Animal Ethics Committee and it was performed in accordance with the Animal Welfare Act and the Guide for the Care and Use of Laboratory Animals, prepared by Dicle University, Animal Ethics Committee.

The rats were divided into the following groups $(n=10)$; Group I: control (distilled water; $10 \mathrm{~mL} / \mathrm{kg}$, po), Group II: L-glutamine (1.5 g/kg, po), Group III: DLM (35 mg/kg, po), and Group IV: DLM (35 mg/kg, po) and after 4 hours L-glutamine $(1.5 \mathrm{~g} / \mathrm{kg}$, po). DLM and L-glutamine were then dissolved in distilled water and administered. ${ }^{14,15}$ The selected dose of DLM was based on previous studies in which 1/5 of the rat's lethal dose 50\% (LD50) induced biochemical alterations in rats. ${ }^{14}$ Animals were treated with an L-glutamine in this dose that was proved to have a neuroprotective effect. ${ }^{11}$ Additionally, the cell protective effect of L-glutamine has been shown at the fourth hour after DLM toxicity in cardiac tissue. ${ }^{16}$

The animals were sacrificed after 24 hours under anesthesia by intraperitoneal administration of a mixture of ketamine (50 mg/mL, 10 mg/kg, Ketalar; Bayer AG, Leverkusen, Germany) and xylazine (2\%, $0.1 \mathrm{~mL} / \mathrm{kg}$, Rompun; Bayer AG) in a solution $(2 \mathrm{~mL} / \mathrm{kg})$. Rats were decapitated. The brains were removed, washed, and perfused with normal saline in order to remove residual blood. For each rat, temporal origins were used for the histopathological studies and the remaining brain tissues were homogenized 1:10 (w/v) in ice-cold $140 \mathrm{mM}$ potassium chloride at $\mathrm{pH}$ 7.4. The homogenates were centrifuged at 3,000 rpm for 10 minutes at $4^{\circ} \mathrm{C}$, and the supernatants were removed and stored at $-80^{\circ} \mathrm{C}$ until the assessment of TNF- $\alpha$, IL-1 $\beta$, IL- 6 , TAS, and TOS levels.

\section{Biochemical analysis}

Measurement of TNF- $\alpha$, IL- 6 , and IL-I $\beta$

The levels of TNF- $\alpha$, IL- 6 , and IL- $1 \beta$ were determined using commercially available rat enzyme-linked immunosorbent assay (eBioscience, Inc., San Diego, CA, USA) kits according to the manufacturer's instructions.

\section{Measurement of TOS}

Tissue TOS levels were determined using a commercially available kit (Rel Assay Diagnostics, Gaziantep, Turkey) developed by Erel. ${ }^{17}$ In this assay, the oxidants present in the sample oxidize the ferrous ion-o-dianisidine complex into ferric ion. The oxidation reaction is enhanced by glycerol molecules, which are abundantly present in the reaction medium. The ferric ion produces a colored complex with 
xylenol orange in an acidic medium. The color intensity, which can be measured spectrophotometrically, is related to the total amount of oxidant molecules present in the sample. The assay is calibrated with hydrogen peroxide, and the results are expressed as $\mu \mathrm{mol} \mathrm{H}_{2} \mathrm{O}_{2}$ equivalent/L.

\section{Measurement of TAS}

Tissue TAS levels were determined using a commercially available kit (Rel Assay Diagnostics) developed by Erel. ${ }^{18}$ In this assay, the antioxidative effect of the sample against the potent-free radical reactions, which is initiated by the produced hydroxyl radical, is measured. The assay possesses excellent precision values, which are $<3 \%$; furthermore, the results are expressed as the mmol Trolox equivalent.

\section{Histopathological analysis}

The histopathology of neurons in each rat's $(n=10)$ temporal origins was observed. The histological slides were examined in a blinded fashion. First, the brain tissues were removed, postfixed for 24 hours in $10 \%$ formaldehyde, and processed for paraffin embedding. After routine processing, paraffin sections of each tissue were cut into $5 \mu \mathrm{m}$ thickness and stained with hematoxylin and eosin. Selected hematoxylin and eosinstained slides were examined with a light microscope (Eclipse E600 microscope; Nikon Corporation, Tokyo, Japan).

Changes in the experimental histopathologic parameters for perineuronal vacuolation and neuronal cell degeneration (cytoplasmic eosinophilia and pyknotic alteration) were graded as follows: (0) showing no change, (1) change in some areas, (2) change in many areas, and (3) extensive change.

For neuropil vacuolization, grading was as follows: (0) showing no change, (1) change in some areas, and (2) extensive change. Perivascular area expansion and vascular congestion were graded as follows: $\times 10$ magnification was counted in four different fields for each case.

\section{Statistical analysis}

Analysis of data was carried out using SPSS 21.0. The data were assessed as mean \pm standard error, and the statistical significance level of the data was determined with oneway analysis of variance followed by the post hoc Tukey's test. $P$-values of $<0.05$ were considered to be statistically significant.

\section{Results}

\section{Histopathological analysis}

In the histopathological examination of the cerebral cortex, there was no difference between groups regarding neuropil vacuolization (Table 1). The DLM group neuronal cell degeneration (pyknosis) in neuronal cells was statistically significant $(P<0.05)$ compared to all other groups (Figure $1 \mathrm{~A}-\mathrm{D}$; Table 1). The DLM group and control group were statistically significant only between perineuronal clearing $(P<0.05)$ (Figure 1A-D). A plurality of vessel structures observed a significant increase in the perivascular areas of glutamine and DLM groups $(P<0.05)$ (Figure $2 \mathrm{~A}-\mathrm{D})$. The number of congested blood vessels was significantly lower in the DLM and glutamine + DLM groups compared to the control and glutamine groups $(P<0.05)$ (Figure $3 \mathrm{~A}-\mathrm{D})$.

\section{Biochemical analysis}

TNF- $\alpha$, IL-6, and IL-1 $\beta$ levels: There was no difference among groups (Figure 4A).

TOS: In Groups III and IV, TOS levels significantly increased in comparison to other groups; however, in Group IV, TOS levels significantly decreased compared to Group III $(P<0.05)$. There was no difference between Groups I and II (Figure 4B).

TAS: In Groups III and IV, TAS levels significantly increased compared to other groups $(P<0.05)$ (Figure 4B).

\section{Discussion}

DLM has been shown to produce marked neurochemical changes in mammalian brains, such as sodium channel activation, the enhanced release of neurotransmitters, and modulation of the phosphorylation of proteins involved in the signaling pathway. ${ }^{19} \mathrm{Wu}$ and $\mathrm{Liu}^{20}$ demonstrated that DLM induces neurodegeneration in vivo and in vitro as well as

Table I The histopathological analysis of the groups

\begin{tabular}{|c|c|c|c|c|c|}
\hline Groups & $\begin{array}{l}\text { Neuropil } \\
\text { vacuolization }\end{array}$ & $\begin{array}{l}\text { Neuronal cell } \\
\text { degeneration (pyknosis) }\end{array}$ & $\begin{array}{l}\text { Perineuronal } \\
\text { clearing }\end{array}$ & $\begin{array}{l}\text { Increased perivascular } \\
\text { (Virchow-Robin) space }\end{array}$ & $\begin{array}{l}\text { Congested } \\
\text { blood vessel }\end{array}$ \\
\hline Group I (control) & $0.20 \pm 0.45$ & 0.00 & $0.20 \pm 0.45$ & $53.40 \pm|0.7|$ & $15.80 \pm 3.27$ \\
\hline Group II (L-glutamine) & $1.00 \pm 1.07$ & $0.62 \pm 0.74^{\mathrm{a}}$ & $0.87 \pm 0.99$ & $82.62 \pm 17.02^{b}$ & $22.87 \pm 6.17^{c}$ \\
\hline Group III (DLM) & $1.40 \pm 0.55$ & $2.20 \pm 1.09^{\mathrm{b}-\mathrm{d}}$ & $1.60 \pm 0.90^{\mathrm{b}}$ & $78.80 \pm 8.10^{\mathrm{b}}$ & $31.40 \pm 3.05^{b}$ \\
\hline Group IV (DLM + L-glutamine) & $1.00 \pm 1.00$ & $0.86 \pm 0.90^{\mathrm{a}}$ & $1.28 \pm 0.49$ & $72.14 \pm 9.92$ & $38.00 \pm 11.16^{b, d}$ \\
\hline
\end{tabular}

Notes: aSignificant compared to Group III; ${ }^{b}$ significant compared to the control group; 'significant compared to Group IV (P<0.05); ${ }^{\mathrm{d}}$ significant compared to Group II. Data presented as mean \pm standard deviation.

Abbreviation: DLM, deltamethrin. 

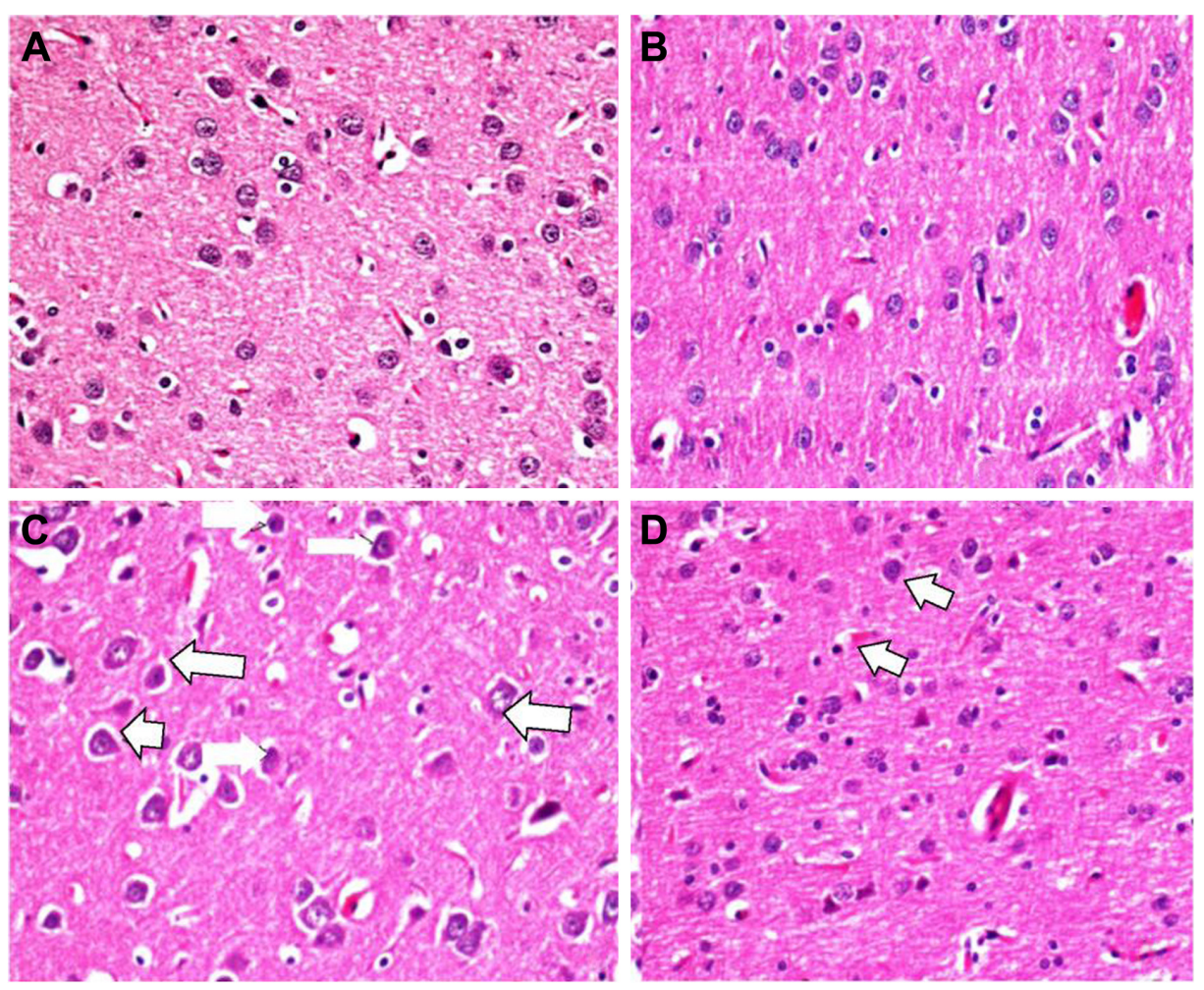

Figure I Evaluation of pyknotic alteration between groups in brain tissue.

Notes: (A) The brain tissue showed no pyknotic alteration in the control group (I), (B) brain tissue showed no cytoplasmic alteration in the glutamine group (II), (C) micrographs of the brain tissue showed a pyknotic alteration and perineuronal clearing (white arrows) in the deltamethrin group (III), (D) brain tissue showed a mediated pyknotic alteration (white arrows) in the glutamine-deltamethrin group (IV), H\&E stain (400X).

Abbreviation: H\&E, hematoxylin and eosin.
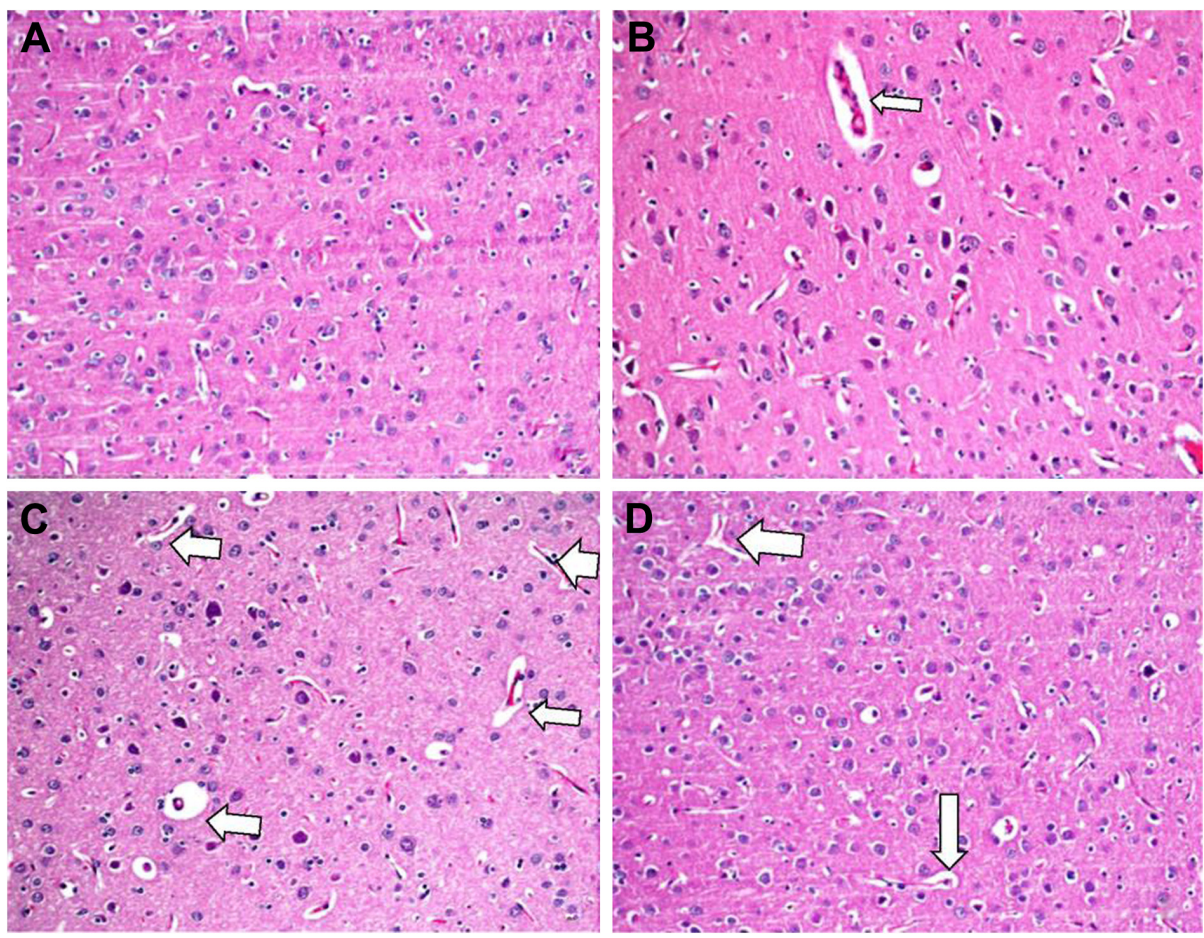

Figure 2 Evaluation of Virchow-Robin space between groups in brain tissue.

Notes: (A) Brain tissue showed no increase in the Virchow-Robin space in the control group (I), (B) brain tissue showed a minimal increase in the Virchow-Robin space (white arrows) in the glutamine group (II), (C) brain tissue showed an increase in the Virchow-Robin space (white arrows) in the deltamethrin group (III), (D) brain tissue showed a minimal increase in the Virchow-Robin space (white arrows) in the glutamine-deltamethrin group (IV), H\&E stain (40×).

Abbreviation: H\&E, hematoxylin and eosin. 

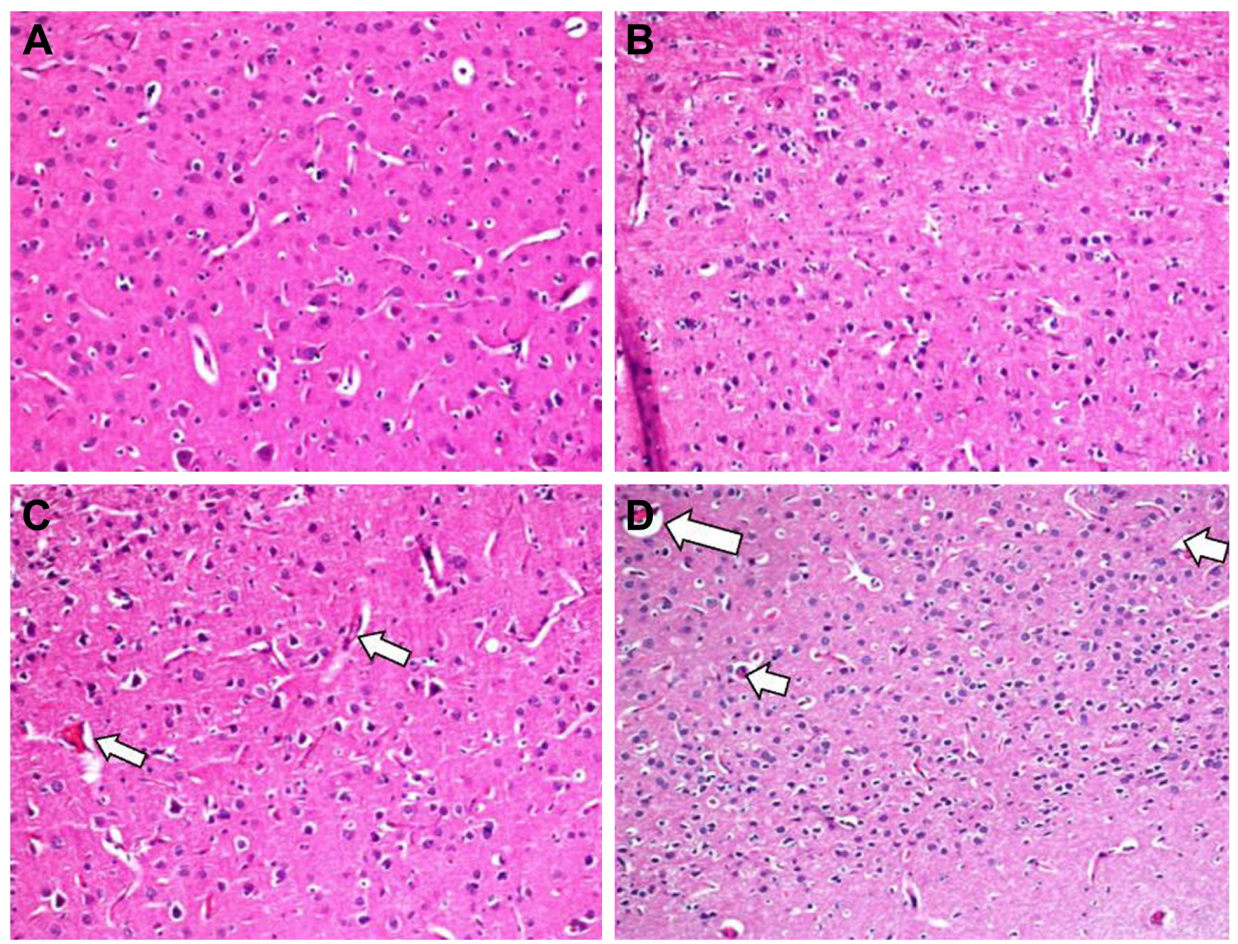

Figure 3 Evaluation of vascular congestion between groups in brain tissue.

Notes: (A) No vascular congestion in the control group (I), (B) normal vascular structure, no congestion in the glutamine group (II), (C) increase in vascular congestion (white arrows) in the deltamethrin group (III), (D) increase in vascular congestion (white arrows) in the deltamethrin + glutamine group (IV), H\&E stain ( $\times$ I00). Abbreviation: H\&E, hematoxylin and eosin.

apoptotic cell death in the brain, which suggests that apoptotic cell death might play an important role in the neurotoxicity of DLM. These neurotoxicity activities could be related to the $\alpha$-cyano group. ${ }^{21}$ Studies of the toxicity of DLM have shown that DLM increases monoamine oxidase activity and decreases in Na+-, K+-ATPase activity in various regions of the central nervous system in rats. ${ }^{22}$ On the other hand,
Romero et $\mathrm{al}^{23}$ showed that metabolites 20-OH-deltamethrin and 40-OH-deltamethrin are more cytotoxic than the parental compound DLM.

Several investigations about DLM toxicity have been published, and few reports have explained the preventive agents used against such toxicity and mechanisms of their ameliorative action. ${ }^{24}$ Abdel-Daim et al showed that DLM treatment
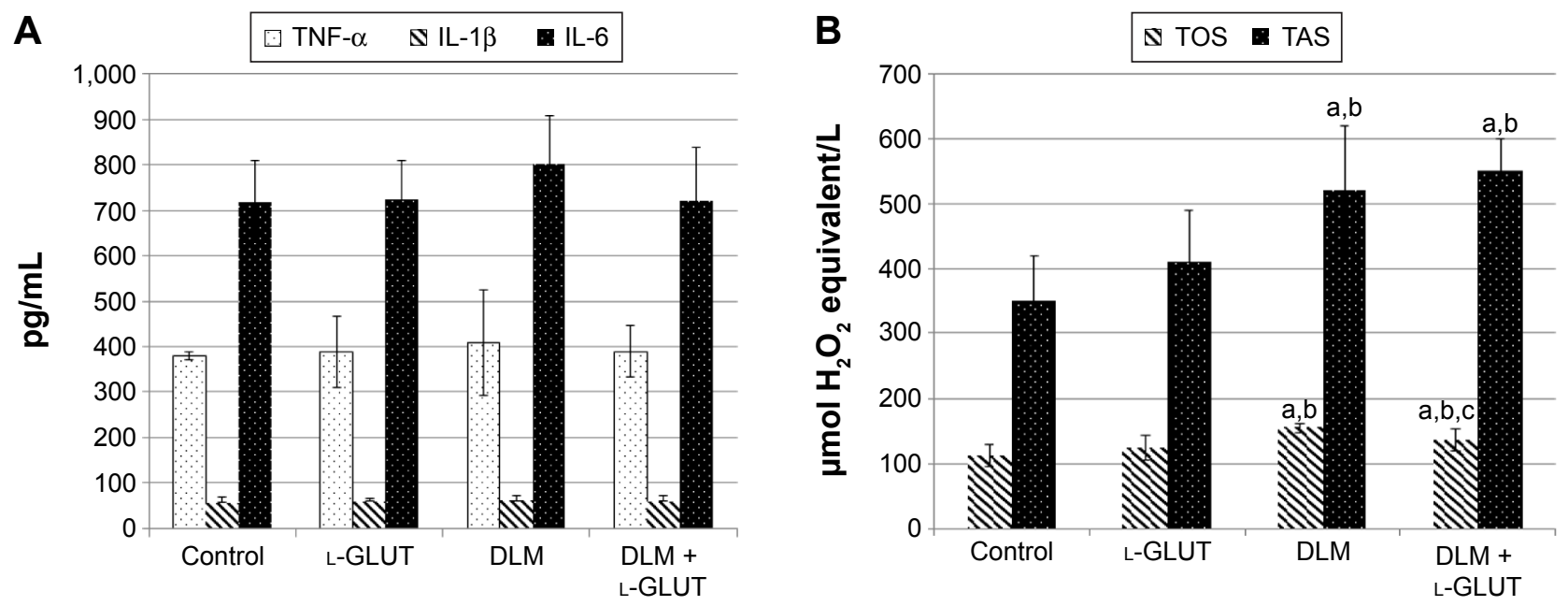

Figure 4 Biochemical analysis of groups.

Notes: (A) The levels of TNF- $\alpha$, IL-I $\beta$ and IL-6 in brain tissue. (B) The levels of TAS AND TOS in brain tissue. There was significance: (a) according to Group I, (b) according to Group II, and (c) according to Group III, $(P<0.05)$.

Abbreviations: TNF- $\alpha$, tumor necrosis factor- $\alpha$; IL, interleukin; L-GLUT, L-glutamine; DLM, deltamethrin; TOS, total oxidant status; TAS, total antioxidant status. 
increased lipid peroxidation through elevated hepatic and renal malondialdehyde levels, decreased hepatic and renal enzymatic, superoxide dismutase and catalase as well as nonenzymatic, GSH antioxidant level and Spirulina platensis normalized the elevated serum levels of aspartate aminotransferase, alanine transaminase alkaline phosphatase, uric acid, urea, and creatinine. S. platensis reduced DLM-induced lipid peroxidation and oxidative stress in a dose-dependent manner. ${ }^{7}$ On the other hand, Abdel-Daim and El-Ghoneimy ${ }^{25}$ showed that the preadministration of ceftriaxone and/or ascorbic acid at a dose level of $100 \mathrm{mg} / \mathrm{kg}$ significantly reduced the serum renal injury markers. Several studies have demonstrated that DLM may induce oxidative stress in rat brains and is consistent with the DLM increase in lipid peroxidation products and decrease in the activities of the antioxidant enzymes superoxide dismutase and GSH reductase in rat brains. ${ }^{26,27}$ This study evaluated the effects of DLM toxicity on oxidative damage, as well as TNF- $\alpha$, IL-6, and IL- $1 \beta$ levels in rat brains. DLM intoxication significantly increased brain TOS and TAS levels. DLM may stimulate adaptive upregulation of some antioxidant enzyme genes, but also excessively increased oxidative damage. However, TNF- $\alpha$, IL-6, and IL-1 $\beta$ levels did not display changes. On the other hand, DLM treatment increased neuronal cell degeneration, perineuronal clearing, and perivascular areas in the cerebral tissue.

Animal studies have demonstrated that glutamine may be neuroprotective and possess immunoregulatory functions. ${ }^{28,29}$ Furthermore, studies have shown that glutamine may affect both oxidative stress and inflammation. ${ }^{30}$ Peng et $\mathrm{al}^{30}$ demonstrated that glutamine-mediated cellular protection following inflammatory cytokine injury is due to heat shock factor-1 expression and the cellular capacity to activate a heat shock protein response. Also, Tsai et al ${ }^{31}$ demonstrated that L-glutamine administration may have increased the reduced GSH to the oxidized GSH ratio, which may result in the prevention of NF- $\mathrm{KB}$ activation and consequently reduce adhesion molecules expression and neutrophil infiltration to the organ. We evaluated the protective effects of glutamine in the DLM toxicity. TAS values increased in the glutamine group compared to the control group; however, it was not statistically significant. L-Glutamine treatment increased TAS and decreased TOS in the DLM + glutamine group compared to the DLM group. Furthermore, it decreased neuronal cell degeneration and perineuronal clearing. These results demonstrate that L-glutamine has an effect on the antioxidants in the damaged brain tissue following DLM toxicity.
A major limitation to this study is that we did not evaluate neurobehavioral changes. Neurobehavioral changes can be seen in rats after DLM intoxication, and those may be improved by treatment with L-glutamine.

\section{Conclusion}

In conclusion, DLM intoxication increased brain oxidative damage and neuronal cell degeneration. L-Glutamine treatment decreased the elevation of brain levels of TOS. L-Glutamine may reduce the toxicity of DLM in brain tissue by reducing oxidative damage.

\section{Disclosure}

The authors report no conflicts of interest in this work.

\section{References}

1. Breckenridge CB, Holden L, Sturgess N, et al. Evidence for a separate mechanism of toxicity for the type I and the type II pyrethroid insecticides. Neurotoxicology. 2009;30:S17-S31.

2. Chandra N, Jain N, Sondhia S, Srivastava A. Deltamethrin induced toxicity and ameliorative effect of alpha-tocopherol in broilers. Bull Environ Contam Toxicol. 2013;90(6):673-678.

3. Organization WH. Guidelines for Drinking-Water Quality: Recommendations. Geneva: World Health Organization; 2004.

4. Barlow S, Sullivan F, Lines J. Risk assessment of the use of deltamethrin on bednets for the prevention of malaria. Food Chem Toxicol. 2001; 39(5):407-422.

5. Soderlund DM, Clark JM, Sheets LP, et al. Mechanisms of pyrethroid neurotoxicity: implications for cumulative risk assessment. Toxicology. 2002;171(1):3-59.

6. Du Y, Song W, Groome JR, Nomura Y, Luo N, Dong K. A negative charge in transmembrane segment 1 of domain II of the cockroach sodium channel is critical for channel gating and action of pyrethroid insecticides. Toxicol Appl Pharmacol. 2010;247(1):53-59.

7. Abdel-Daim MM, Abuzead S, Halawa SM. Protective role of Spirulina platensis against acute deltamethrin-induced toxicity in rats. PLoS One. 2013;8(9):e72991.

8. Narahashi T. Cellular and molecular mechanisms of action of insecticides: neurophysiological approach. Neurobehav Toxicol Teratol. 1981; 4(6): $753-758$

9. Novak F, Heyland DK, Avenell A, Drover JW, Su X. Glutamine supplementation in serious illness: a systematic review of the evidence*. Crit Care Med. 2002;30(9):2022-2029.

10. Melis GC, ter Wengel N, Boelens PG, van Leeuwen PA. Glutamine: recent developments in research on the clinical significance of glutamine. Curr Opin Clin Nutr Metab Care. 2004;7(1):59-70.

11. Wischmeyer PE, Jayakar D, Williams U, et al. Single dose of glutamine enhances myocardial tissue metabolism, glutathione content, and improves myocardial function after ischemia-reperfusion injury. JPEN J Parenter Enteral Nutr. 2003;27(6):396-403.

12. Gündüz E, Ülger BV, İbiloğlu İ, et al. Glutamine provides effective protection against deltamethrin-induced acute hepatotoxicity in rats but not against nephrotoxicity. Med Sci Monit. 2015;21:1107.

13. Todorova VK, Kaufmann Y, Hennings L, Klimberg VS. Oral glutamine protects against acute doxorubicin-induced cardiotoxicity of tumorbearing rats. $J$ Nutr. 2010;140(1):44-48.

14. Weiner ML, Nemec M, Sheets L, Sargent D, Breckenridge C. Comparative functional observational battery study of twelve commercial pyrethroid insecticides in male rats following acute oral exposure. Neurotoxicology. 2009;30:S1-S16. 
15. Zhang Y, Yan H, Lv S-G, et al. Effects of glycyl-glutamine dipeptide supplementation on myocardial damage and cardiac function in rats after severe burn injury. Int J Clin Exp Pathol. 2013;6(5):821.

16. Aydin M, Yildiz A, Ibiloglu I, et al. The protective role of glutamine against acute induced toxicity in rats. Toxicol Mech Methods. 2015; 25(4):296-301.

17. Erel O. A new automated colorimetric method for measuring total oxidant status. Clin Biochem. 2005;38(12):1103-1111.

18. Erel O. A novel automated method to measure total antioxidant response against potent free radical reactions. Clin Biochem. 2004;37(2): 112-119.

19. Sharma P, Jan M, Singh R. Deltamethrin toxicity: a review. Ind J Biol Stud Res. 2013;2(2):91-107.

20. Wu A, Liu Y. Apoptotic cell death in rat brain following deltamethrin treatment. Neurosci Lett. 2000;279(2):85-88.

21. Wolansky M, Harrill J. Neurobehavioral toxicology of pyrethroid insecticides in adult animals: a critical review. Neurotoxicol Teratol. 2008;30(2):55-78

22. Husain R, Husain R, Adhami VM, Seth PK. Behavioral, neurochemical, and neuromorphological effects of deltamethrin in adult rats. $J$ Toxicol Environ Health. 1996;48(5):515-526.

23. Romero A, Ramos E, Castellano V, et al. Cytotoxicity induced by deltamethrin and its metabolites in SH-SY5Y cells can be differentially prevented by selected antioxidants. Toxicol In Vitro. 2012;26(6): 823-830.

24. Abdel-Daim MM, Abd Eldaim MA, Mahmoud MM. Trigonella foenum-graecum protection against deltamethrin-induced toxic effects on haematological, biochemical, and oxidative stress parameters in rats. Can J Physiol Pharmacol. 2014;92(8):679-685.
25. Abdel-Daim MM, El-Ghoneimy A. Synergistic protective effects of ceftriaxone and ascorbic acid against subacute deltamethrin-induced nephrotoxicity in rats. Ren Fail. 2015;37(2):297-304.

26. Li HY, Shi N, Chen D, et al. [Oxidative stress of deltamethrin on rat nervous system]. Zhonghua Lao Dong Wei Sheng Zhi Ye Bing Za Zhi. 2005;23(2):97-101. Chinese.

27. Li H, Wu S, Ma Q, Shi N. The pesticide deltamethrin increases free radical production and promotes nuclear translocation of the stress response transcription factor Nrf2 in rat brain. Toxicol Ind Health. 2011; 27(7):579-590.

28. Roth E, Oehler R, Manhart N, et al. Regulative potential of glutaminerelation to glutathione metabolism. Nutrition. 2002;18(3):217-221.

29. Zhao YJ, Fu JH, Sun M. Effects of glutamine on platelet-derived growth factor and its receptor following septic brain damage in rats. Zhongguo Dang Dai Er Ke Za Zhi. 2010;12(12):967-971.

30. Peng Z-Y, Hamiel CR, Banerjee A, Wischmeyer PE, Friese RS, Wischmeyer P. Glutamine attenuation of cell death and inducible nitric oxide synthase expression following inflammatory cytokine-induced injury is dependent on heat shock factor-1 expression. JPENJ Parenter Enteral Nutr. 2006;30(5):400-407.

31. Tsai P-H, Liu J-J, Chiu W-C, Pai M-H, Yeh S-L. Effects of dietary glutamine on adhesion molecule expression and oxidative stress in mice with streptozotocin-induced type 1 diabetes. Clin Nutr. 2011;30(1): 124-129.
Neuropsychiatric Disease and Treatment

\section{Publish your work in this journal}

Neuropsychiatric Disease and Treatment is an international, peerreviewed journal of clinical therapeutics and pharmacology focusing on concise rapid reporting of clinical or pre-clinical studies on a range of neuropsychiatric and neurological disorders. This journal is indexed on PubMed Central, the 'PsycINFO' database and CAS,

\section{Dovepress}

and is the official journal of The International Neuropsychiatric Association (INA). The manuscript management system is completely online and includes a very quick and fair peer-review system, which is all easy to use. Visit http://www.dovepress.com/testimonials.php to read real quotes from published authors. 